\title{
Maritime Nation or Maritime Narrative: The Humanist Case for Canada
}

\section{Michael L. Hadley}

En quoi consiste une nation maritime et la question de savoir si le Canada peut être considéré comme une telle nation sont des thèmes généralement abordés par les historiens, les politicologues et les analystes de politiques. Le présent article vient contribuer à cette réflexion du point de vue humaniste en soutenant que l'identité du Canada sefonde, en termes culturels et littéraires, sur son expérience maritime. S'inspirant du large contexte culturel évoqué par la conférence de 2016 intitulée "Where Rivers Meet Oceans » de la Société canadienne pour la recherche nautique, il propose une gamme impressionniste de documents littéraires et sociaux à l'appui de cette perspective. En fin de compte, toute prétention au statut de nation maritime dépend non pas de définitions, mais bien de l'ampleur et de la qualité du patrimoine d'un pays

Is Canada a maritime nation? The answer seems a matter of opinion. Conventional wisdom shapes the discourse in terms of trade, commerce and defence, and hangs it all on the hook of a one-size-fits-all definition. Thus, it is argued, a country whose borders are encompassed by the sea - and which depends on the sea for its security and economic health - fits the bill. There are variations of this definition, of course. But what if the country is not entirely encompassed, but still has maritime interests? Or if its commerce is overwhelmingly transborder? Alternatively, those promoting naval interests tend to emphasize the primary importance of combat-capable fleets and sovereignty patrols. The bottom line is the extent to which a country can contribute meaningfully to maritime alliances. Canada today has one of the smallest navies, yet one with a global mission. With a nostalgic glance at the halcyon days of the Second World War when the Royal Canadian Navy was the third (some say the fourth) largest fleet in the world, some argue that Canada could yet make a significant comeback. That is possible, arguments run, if only Canadians understood the importance of the sea and a navy. It is an oft-repeated lament best captured by Victor Suthren's The Island of Canada: How Three Oceans Shaped Our Nation (2009). In his words: "There is no nation with a greater physical connection with the

The Northern Mariner/Le marin du nord, XXVII, No. 4 (Oct. 2017), 339-53. 
sea than Canada, and there are few people with such a stunning wealth of seacoast who are as unaware, or unknowing, of that connection as Canadians." ${ }^{1}$ Of course, he is right.

In the light of such widespread "ignorance," proponents of the view that Canada is - or could be - a maritime nation have tried over the years to educate its citizens about the importance of the sea. Ironically, writers tend to restrict their audience to those who read professional nautical journals. To such writers, the best hope for getting the message across to the public depends upon a government with the "right" policy. Thus one policy analyst has typically argued that "leadership is called for that will inform Canadians that they are part of a maritime nation."2 He noted that "twentieth-century political rhetoric urgently needs to be updated in keeping with the maritime responsibilities Canada must adopt in the twenty-first century." He insisted that pursuant to the Canada Oceans Act our shorelines "must be treated with equal respect." Indeed, he pointed out, the UN's Convention of the Law of the Sea actually "requires Canada to define and defend its sovereignty in terms of its maritime domain." Other voices simply assert that Canada is a maritime nation, and leave it at that. ${ }^{3}$

Perhaps there is another approach. Perhaps it is far more important that we Canadians first recognize who we are as a people. Many national themes pop out of the cultural identity kit: Canada as peacemaker, its biculturalism and bilingualism, multiculturalism and mutual accommodation - and the most consistently debated of the lot, Margaret Atwood's twin themes of survival and victimhood. ${ }^{4}$ Significantly, none of these are foundational or sustaining identities. Yet despite such evidence, some observers still lament that Canada today lacks "a compelling national narrative." ${ }^{, 5}$ Here is where the sea comes in.

One public opening to this issue occurred in 2015 when The Royal Society of Canada hosted a scientific symposium to address the complex question of "Marine Biodiversity." Unusual for a scientific conference at this level, the creative organizers had invited a humanist to reflect on what oceans and biodiversity mean in human experience. Here's what she said: "Measurement is important - but it isn't everything. The values of the sea are profoundly expressed in poetry, creative

\footnotetext{
${ }^{1}$ Victor Suthren, The Island of Canada: How Three Oceans Shaped Our Nation (Toronto: Thomas Allen Publishers 2009), 1.

2 Tim Lynch, "Is Canada an Arctic Nation or a Maritime Nation?" Canadian Naval Review, 2012. www.navalreview.ca/2012/01/is-canada-an-arctic-nation-or-a-maritime-nation/ Accessed 23 August 2017.

3 See, for example, Adam P. Macdonald, "Canada must be prepared to support its military allies in the Pacific," in MLI Commentary, A Macdonald-Laurier Publication, August 2017, $1,7$. www.Macdonald-Laurier.com. He insists, among other things, that Canada is "a maritime nation supportive of the international order;" one indeed that fosters a "national interest as a maritime state."

${ }^{4}$ Margaret Atwood, Survival: a Thematic Guide to Canadian Literature (Toronto: Anansi Press, 1972).

${ }_{5}^{5}$ Hussan Arif. "Searching for Canada's National Narrative," in Huffington Post blog, Huffpost. 14 April 2011, online. Significantly, the writer is searching for a political answer.
} 
writing...." And then she continued: "People don't just use the ocean, economically speaking. We don't just 'take inventories of the sea.' We sing songs about the sea and its shores, in many languages, make documentary films about the sea and its creatures, and write poetry and novels about it and its importance for human beings." She spoke with authority, for her Coasts Under Stress (2007) had uniquely blended both humanist and scientific analyses with testimony from the lived experience of coastal people. ${ }^{7}$ She had played a leading role in a further stage of the "coasts under stress project." Published as Making and Moving Knowledge, it applied Humanities, Social Science and Science knowledge - together with community wisdom - to our relationship with the oceans on our coasts. ${ }^{8}$ Oceanographer Jeffrey Hutchings, from Dalhousie University, concluded the symposium in an upbeat tone by noting that the sea is one of the top keystone narratives of Canadian identity and values. That is the hook for any public awareness program.

By the time of that symposium, a major study of Canadian nautical writing had long since been underway. Its substantive material embraced all the genres from passage logs to memoir, from poetry to novel and song, and examined the testimony of seafarers and non-seafarers alike. A critical sampling of this broader study appeared in the summer of 2017 under the title Spindrift: a Canadian Book of the Sea. ${ }^{9}$ The researchers addressed a series of fundamental questions: How do Canadians relate to the sea? How have they always done so, and what have they experienced? Researchers drew upon writers with the most diverse experience, and ranged from the oral traditions of aboriginal peoples to cultural documents of the present day. The insights gained ran counter to the inherited wisdom that seas are primarily of economic or strategic interest. Importantly, the evidence that Canada is indeed a maritime nation with a rich cultural history is already out in the public arena, and has been there for generations. Canadians do not need to rachet up the political rhetoric, or await yet another government policy statement on the subject.

This shift in focus from quantitative to qualitative research - or better still, this blending of the two - may not be particularly comfortable for technical readers, for it takes us into the realm of aesthetics. Aesthetics, we might remind ourselves, comes from the Greek word for "perception" and is the branch of philosophy dealing with the beautiful. Aesthetics points to the existential centre of what it

\footnotetext{
${ }^{6}$ Rosemary E. Ommer, keynote address to the Royal Society of Canada's annual symposium "Marine Biodiversity," November 2015, Victoria, BC.

${ }^{7}$ Rosemary E. Ommer, and the Coasts Under Stress Research Project Team, Coasts Under Stress: Restructuring and Social-Ecological Health (Montreal and Kingston: McGill-Queen's University Press, 2007).

${ }^{8}$ John Sutton Lutz and Barbara Neis, eds., Making and Moving Knowledge: Interdisciplinary and Community-based Research in a World on the Edge (Montreal and Kingston: McGill-Queen's University Press, 2008).

${ }^{9}$ Michael L. Hadley and Anita Hadley, eds., Spindrift: a Canadian Book of the Sea (Vancouver, BC: Douglas \& McIntyre, 2017).
} 
means to be a human being. It has little to do with what is merely decorative or pretty. Central to scholarship in the Humanities is an appreciation of symbolic thinking for their enterprise. ${ }^{10}$ But this does not come without challenges for interdisciplinary work. As Germany's classical poet Goethe once put it: "A man born to and trained in the so-called exact sciences, and fully matured in his powers of reason, will not find it easy to understand that there is such a thing as an exact sensuous imagination." "As an example, take the confession of the late Captain Andy Publicover, skipper of the Lunenburg schooner W.N. Zwicker: "I never could have lived far from the salt water or the salt air, because the sea runs in my blood." 12 Scientifically suspect, but aesthetically and experientially right on target.

What this means can be seen in essence by taking up the under-discussed theme of the Canadian Nautical Research Society's conference entitled "Where Rivers Meet Oceans." It was held in August 2016 in New Westminster, BC, near the mouth of the Fraser River. The creative title of that conference invited us to contemplate a set of unique living legacies: estuaries teeming with life and with history, and sustained by stories, myths and memory. Such tidal waters form one of the most productive types of ecosystem on the planet. (The Mackenzie and St. Lawrence Rivers are further cases in point). These legacies underpin national identity. In both a real and a metaphorical sense, these tidal waters where rivers meet oceans tell a national story, one in need of our constant stewardship. We can capture them in sets of tell-tale images: ship-building, fisheries, exploration and commerce, immigrant stations and scenes of exile, the rise and fall of settlements, combat, and of course millennia of Aboriginal culture.

One could tell a number of quite different stories about each river mouth across the country. One could, perhaps, write a whole cultural history of places where rivers meet oceans. And maybe we should. "Where rivers meet oceans" is both a real and a mythical place that both reflects and creates varieties of Canadian experience. All of this sheds light on what it means to be a maritime nation. A cursory and impressionistic survey from the west, via the arctic, to the east will suggest what I mean.

Today, the Fraser boasts a major deep-sea port: Fraser River Port. That was its name until 1 January 2008 when it combined with both the North Fraser Port Authority and the Vancouver Port Authority to form Port Metro Vancouver. Each year, as the port's publications announce, the docks on the river handle some 36 million tons of cargo, 95 thousand TEUs (twenty-foot equivalent units) of

\footnotetext{
10 Rosemary E. Ommer, Harold Coward and Christopher C. Parrish, "Knowledge, Uncertainty and Wisdom," in Lutz and Neis, 20-41.

11 Johann Wolfgang von Goethe (1749-1832), cited in Herbert Read, The Tenth Muse: Essays in Criticism (London: Routledge \& Kegan Paul, 1957). See chapter 5, "Goethe and Art." For the original see, Goethe, Werke, ed., Erich Trunz, Hamburg: Christian Wegner Verlag, 4. Aufl., 1962, vol. 13, 42. Goethe used the term "exakte sinnliche Phantasie."

${ }^{12}$ See James Richards and Marleen Richards, with Eric Hustvedt, The Sea in My Blood: The Life and Times of Captain Andy Publicover (Hantsport, NS: Lancelot Press Limited, 1986).
} 
containerized cargo, and almost 465 thousand vehicles. So much for the port's technical significance. What the port actually means for the country requires knowledge of a different order.

We find many testimonies to the impact of the sea in the works of a wealth of Canadian writers. Take for example, poet and novelist Tim Bowling, who grew up in the river's fishing village of Ladner and worked the estuary as a professional fisherman. He is one of many witnesses steeped in the river's lore. His remarkable novel The Tinsmith (2012), conjures up life in the lower Fraser with a huge fishing fleet and over twenty-two canneries during the 1880s. He paints lively images of the "Royal City" of New Westminster, which was to have been the capital of British Columbia. He writes of the city bustling and bursting with "the smell of money" wafting up from the river and into the hotels and bars; he speaks of the river banks "reaking of fish and sweat." He evokes all the colour of mixed-race labour along cannery row at the river mouth.

His memoir The Lost Coast: salmon, memory and the death of wild culture shares his childhood memories of the last days of large-scale gillnetting in the tidal waters of Ladner, a few kilometres from the river's confluence with the Strait of Georgia. These were the waters in which he himself once fished as an adult, and where - even as a boy - he developed a philosophy of life. Confronting the natural world, he observed rich patterns of creation everywhere, and came to accept death as a natural part of these patterns. The river taught him a whole ethos, and that human knowledge is limited.

His book is in many respects a deeply meditated work about the once great bounty of the riverine and ocean fisheries - and of bounty betrayed by greed, overfishing, and general lack of respect for the environment. But woven throughout the book are threads of reverence, fascination, and even hope in the midst of despair. And the life of the Fraser River was to him a maturing, global affair. As Bowling reflected during one of his fishing ventures into the estuary leading into the broad waters of the Strait of Georgia, or what we now call the Salish Sea:

I wasn't standing merely on the scuffed hatch-cover of a salmon gillnetter; this was a threshold to a world that extended beyond one place and one language, reached out to a world of similar small and unsung places and of huge, much-chronicled cities, of thousands of languages, billions of people, the living, the dead, the not-yet-born, whole civilizations I could participate in simply by virtue of having a tongue and a portion of the loved earth in which to sow desire. ${ }^{13}$

"Sowing desire" is short-hand for creating culture. In that sense, desire has been sown for thousands of years at the mouth of the Fraser. The Fraser estuary, site of

\footnotetext{
13 Tim Bowling, The Lost Coast: salmon, memory and the death of wild culture (Gibson's Landing:
} Nightwood Editions, 2007), 26. 
the Great Marpole Midden which has been proclaimed a national historical site, provides both archeological and anthropological evidence that this area has been the home of the Coast Salish people for thousands of years. Indeed, archeological sites throughout the West Coast of $\mathrm{BC}$-celebrated by UBC's Museum of Anthropology - attest to the equally deep-rooted presence of First Nations' habitations. Today, mariners hear echoes of this legacy on VHF radio when marine broadcasts announce the rhythmic opening/closures of the Fraser River to Aboriginal drift-net and set-net fisheries. To some people, these broadcasts are an example of belated natural justice.

Old-timers familiar with the tidal waters of the Fraser estuary still recall poignant moments that weave symbolic patterns: rust-stained tramp streamers from the Orient working their way along the buoyed channels; the "music" of the old Easthope "one lung" gasoline engines that in the 1940s and '50s propelled the livetank cod boats from their fishing grounds to the many canneries that lined the river's banks; the large fleets of chunky, colourful tugs, and the smells of canneries and sawmills; they remember seeing in 1942 the fleet of "Japanese" fishing boats confiscated by the Royal Canadian Navy in support of a racially motivated defence policy; they can still hear the disturbing keening of an old Japanese fisherman that same year in the almost deserted fishing village of Steveston lamenting the loss of his boat, his home and his livelihood. The estuary abounds in cultural resonances.

Casting his mind back over the millennia of cultural, political and economic change, Bowling reflects on what "ultimately" matters:

Eventually, one tires of the relentless human struggle for justice and simply lets the earth's splendor fill the eyes and veins. I'm drifting down a great river where I was once a boy standing in the stern of a boat beside my father. It's no wonder T.S. Eliot described rivers as strong, brown gods, for the holy is more palpable here than in any church, the flow of the silts more humbling and inspiring than the flow of any saviour's blood. ${ }^{14}$

This deep-rootedness is found in other BC estuaries as well. One thinks, for example, of the Nisga' a people, who have been living since time immemorial in the remote region of Northern BC. They, too, had developed a sophisticated form of West Coast culture. They were the first to have fished and built boats in the tidal waters of the Nass River. Significantly, they were the first native group to launch a legally constituted land-claims action against the Canadian government. The experience of the rich oolichan run remains what it has been for generations-apart from some modern marine technology. Writer Tom Koppel captured the life of the Nisga'a and conjured up their perennial rituals. ${ }^{15}$

\footnotetext{
${ }^{14}$ Ibid., 253.

15 Tom Koppel, Ebb and Flow: Tides and Life on Our Once and Future Planet (Toronto: Dundurn Press, 2007). 171-73.
} 
His experience with the Nisga'a resonates with that of Newfoundlanders catching capelin. In fact, we find resonances with oceans and rivers right across the country. Even in the prairies writers speak of a compelling nostalgia. Charles G.D. Roberts (1860-1943), for example, put it this way in his poem "Beside the Winter Sea" (he was in Ontario at the time):

As one who sleeps, and hears across his dream

The cry of battles ended long ago,

Inland I hear the calling of the sea. I hear its hollow voices, though between

My wind-worn dwelling and thy wave-worn strand

How many miles, how many mountains are! ${ }^{16}$

"Inland I hear the calling of the sea," Roberts had written. But, where exactly is "inland," we might ask. Sitting in his university office in Edmonton, novelist Rudy Wiebe pondered what it means, and found a creative answer that challenges us to re-imagine our geographical relationships. In doing so, he found a poetic link with rivers: "But "inland" is a convenient chimera, a mythological beast concocted by our refusal to imagine and thereby to understand." He then reversed our "scientific" view that rivers run "downhill" into the sea. He put it this way: "when you approach a river from the ocean it becomes much more enlightening to recognize that rivers are the gnarled fresh fingers of the sea reaching for the mountains." "17

With that cast of mind he looked out his office window toward the North Saskatchewan River; he envisioned the Athabaska, Slave and Mackenzie Rivers, and recognized them as "tentacles of the Circumpolar Sea." To him, this large body of water was "that great global sea which surrounds us and in so doing defines our true boundaries." No wonder, he adds, that the first people to explore the Arctic tundra were not landsmen, but sailors. So, what does this mean to the novelist and professor of English literature? This vision of rivers: "affirms the idea that movement within a landscape, whether on water or occasionally land, can be seen in the linear image of water moving down to the sea, or, if you grant me my original reversed conceit, of the rivers being the tentacles of the protean sea reaching over the land. In other words, the movement (life) of human beings is always analogous to the line water draws upon land." 18

The Mackenzie River is one such line which "water draws upon land." For generations it was the annual route of "Eskimos" to the Whitefish Station on the Beaufort Sea where families hunted whale. Alice French's delightful memoir My

16 Desmond Pacey, ed., The Collected Poems of Sir Charles G.D. Roberts (Wolfville, NS: The Wombat Press, 1985), 223.

17 Rudy Wiebe, Playing Dead: A contemplation concerning the Arctic (Edmonton: NeWest Press, 1989), 12-13, 77-78.

${ }^{18}$ Ibid., 78. 
Name is Masak (1976) tells of her growing up in the Arctic prior to the Second World War, and her summer journeys northward after the great thaw, past occasional small settlements and lonely trappers' cabins; on beyond the tree line, in ever greater expectation of the change of life which the journey brings. As she wrote: "As we got closer to the coast the landscape started to change. The trees got fewer and smaller. Soon there were no trees, just gently rolling hills, gravel beaches, and clear blue water. The muddy waters of the Mackenzie River were left behind and we sailed along on the clear, clean-smelling sea." ${ }^{\prime 19}$

And then - utter release, even exultation, on arrival: "There was not a tree to hamper the vision of sea and sky and land. On a clear day we could see the mirage of Tuktoyaktuk hanging upside down in the sky and Kiklavik Bay, ten miles across the ocean." And so their summer of whaling began. It was, in effect, a private affair of subsistence hunting in which few but the Inuit took interest. But it was the depredations of foreign whale-hunters in the estuaries of the Arctic that arguably pushed the Canadian government into a new relationship with its northern waters. (But that story is for another day).

The enterprise of commercial whaling had encompassed all three coasts over four centuries: from Basque "incursions" in the sixteenth century, to the "exploitative" ventures by major European powers in the seventeenth and eighteenth, to the nineteenth century pursuit of whales on the West Coast by "marauding" Americans. Of course, Canadians had been involved as well. One thinks, not only of the short-lived Canadian industry operating on Vancouver Island and in the Strait of Georgia during the years 1868-1872, but of the longer whaling tradition pursued by fishers in Newfoundland and Labrador. The charged language resorted to here- "incursions," "marauding," "exploitative"-reflect the heated emotions that have coloured debate about the whaling industry. The courage of the whalemen, however, remains beyond dispute.

The federal government's concerns with sovereignty over its Arctic archipelago and its natural resources became a pressing issue in the 1970s. National defence issues heightened the importance of Canadian claims. Yet at the end of the day, it is the quality of life in the North - not national defence - that has captured the creative imagination. Significantly, it is the province of Manitoba - rarely perceived in its rightful aspect as a seabound "maritime" province - that serves as the strongest protector of the once endangered whales. In the estuaries of the Churchill, Nelson and Seal Rivers in western Hudson's Bay, this supposedly "inland" prairie province boasts a protected habitat for the largest concentration of beluga whales in the world.

Each summer, some three thousand belugas enter the comparatively warmer waters of the Churchill River estuary, to give birth and raise their young. It is a scene almost lifted out of Jules Verne's futuristic Twenty-Thousand Leagues under

${ }^{19}$ Alice French, My Name is Masak (Winnipeg: Peguis Publishers, 1976), 70. 
the Sea, published in 1870. But unlike Verne's science fiction, the scene, unrolling within sight of Canada's primary Arctic sea port Churchill, is filled with reality and splendid colour. Film director Peter Mettler's National Film Board production Picture of Light (1994) described Churchill as "a meeting place of edges; ocean and land, Indian and Inuit, trees and tundra, the real wild and the uncivilized south." Thus it was that journalist and photographer John Zada, dressed in his diving kit, experienced a unique Canadian scene as he slipped beneath the waves. The tension is palpable as two types of sentient beings - humans and beluga whales - explore the interfaces between their worlds in this prairie seascape and, perhaps, who knows, attempt some form of communication:

In seconds I'm in the frigid water holding onto a towrope and staring into the murky Leviathan depths. Pale blurs soon become visible in the distance. Then, without warning, the phantom-like whales appear directly beneath me, turning sideways and gazing up with their benevolent expressions of stoic curiosity. The belugas appear with remarkable clarity and approach in groups of three or four, coming as close as a few metres away. The water is filled with whale chatter: a mixture of bird-like chirping noises and bursts of sound not unlike short-wave radio static. It is a surreal and moving experience. $^{20}$

We have now reached what is broadly known as Central Canada. The network of rivers associated with the early days of the Fur Trade in what Donald Creighton called "the grand strategy of empire." The fierce competition between English and French will be largely familiar to this readership. Suffice it to say here, that whereas the Hudson's Bay Company had been transporting the richest cargoes of furs from south to north to areas of the Churchill River estuary (over which French and English had a fought a sea battle in 1697_-and France's d'Iberville had won) - the French had been systematically moving from east to north-west via rivers and lakes from Grand Portage at the head of Lake Superior. In doing so, the French had been incorporating the territory into - Donald Creighton again — "the continental trading system of the St. Lawrence." ${ }^{21}$ Rudy Wiebe's lines of water again - reaching far inland from the St. Lawrence with its growing history of migration, settlement, trade, conflict, and war. Here lay the beginnings of the St. Lawrence Seaway.

The Seaway began with a vision-Lt. Col. John By's letters of the 1820s are a case in point - and ended as an astounding reality: deep-sea ships from the open Atlantic penetrating far into the Great Lakes, thus adding an Eighth Sea to the legendary Seven. Lieutenant-Colonel John By of the Royal Engineers frequently

\footnotetext{
${ }^{20}$ John Zada, "Churchill: on Canada's Arctic Edge," first published on Travel Section, The National, 09 August 2014. Located at www.johnzada.com/on-canada-arctic-edge-churchill-manitoba-polarbears-beluga-whales/ Accessed on 02 February 2016.

${ }^{21}$ Donald Creighton, The Story of Canada, (Toronto: Macmillan, 1960), 56-57.
} 
reflected on the possible canal system that could link the Inland Sea with the international port of Quebec. Reading his correspondence, one is repeatedly reminded just how prescient he was. Take, for example, his letter of 13 July 1826:

on examining the Military Defences of Canada, it appears self-evident, that by forming a Steam boat navigation from the River St. Lawrence to the various Lakes, would at once deprive the Americans of the means of attacking Canada; and would make Great Britain mistress of the trade of that vast population on the borders of the Lakes... . I therefore strongly recommend the Welland, the Rideau, and the Grenville Canals being constructed on a scale sufficient to pass these Steam boats. ${ }^{22}$

Colonel By completed the Rideau Canal in 1832.

That same year, the vast panorama which he had envisaged from the Atlantic to the Great Lakes was unrolled imaginatively before a voracious reading-public in a best-selling romantic novel: Wacousta: or the Prophecy, a Tale of the Canadas, by Canadian-born novelist Major John Richardson. It was in many respects a response to an American best seller, James Fenimore Cooper's The Last of the Mohicans (1826) which had captured the imagination of a wide reading public. Richardson's, too, became a literary hit. Whereas Cooper had based his historical novel on events in the emerging USA around 1757, Richardson drew upon events in Canadian history between the years 1763-1812. The literary result was a gothic romance. But in place of the usual castle ruins, monsters and heroines normally associated with the gothic genre, Richardson set the action in what he called "the thick, impervious, rayless forest," with its cast of explorers, hunters and warriors.

Such scenes were more than merely gothic requisites; they were the world of the Canadas as Richardson knew it. In setting the scene for a readership unfamiliar with the North American lakes and rivers, he opened his work with a vast panorama of what over one-hundred fifty years later would become the St. Lawrence Seaway: "That portion of the northern continent of America which is known as the United States is divided from the Canadas by a continuous chain of lakes and rivers, commencing at the ocean into which they empty themselves, and extending in a north-western direction to the remotest parts of these wild regions, which have never yet been pressed by other footsteps than those of the native hunters of the soil., ${ }^{23}$

His panoramic scene-setting cast a discerning eye over fortifications, warships, and "even a ship of one hundred and twelve guns, manned by a crew of one

\footnotetext{
${ }^{22}$ Lt. Col. John By, letter to General Gother Mann, 13 July 1826., in Roberta M. Styran and Robert R. Taylor. The "Great Swivel Link": Canada's Welland Canal. (Toronto: The Champlain Society, 2001),79 - 81.

${ }^{23}$ John Richardson, Wacousta: or, The Prophecy, a Tale of the Canadas. (1832), (Toronto: McLelland and Stewart, 1967), 1-3.
} 
thousand men, [that] reflected the proud pennants of England!" And of course, he reminded his readers of that rather bothersome "independent republic," the USA.

And finally, having with broad brush-strokes reached the port of Quebec, the tale of this romantic novelist emerges in what was the theme of the CNRS conference in August 2016 "Where Rivers Meet Oceans": "From this point the St. Lawrence increases in expanse, until, at length, after traversing a country where the traces of civilisation become gradually less and less visible, she finally merges in the gulf, from the centre of which the shores on either hand are often invisible to the naked eye; and in this manner it is imperceptibly lost in that misty ocean, so dangerous to mariners from its deceptive and almost perpetual fogs."

That's how it looked to the novelist in 1832. Now embracing over one hundred ports, the St. Lawrence Seaway carries over 160 million tons of cargo annually. Over half of this runs between international ports in Europe, the Middle East and Africa. Today, the trade agreement between Canada and the European Union known as CETA has spurred new marine routes with Montreal and beyond. ${ }^{24}$ Again, if we wish to adopt Rudy Wiebe's poetic model, the seaway is a "finger of the Protean sea" reaching inland-yes, even unto Toronto, a major inland deep-sea port that, among other things, plays host to some ten thousand recreational boaters.

Like the sea, the Great Lakes in their various moods have also engaged the creative imagination. So, too, the network of rivers leading from the sea. St. Lawrence lore now embraces the whole length of this network. (It also makes it far more difficult to state where - exactly_ "rivers meet oceans.")

Take, for example, Gordon Lightfoot's ballad "The wreck of the Edmund Fitzgerald" which, not surprisingly, is often seen as a St. Lawrence song. November is notorious for storms in the Great Lakes. Coming up suddenly, they can cause serious difficulties for those "lakers" and "salties" making their final runs before the close of the navigation season. On 10 November 1975 the US registered bulk carrier SS Edmund Fitzgerald, the largest lake vessel ever launched at the time, encountered one of the worst storms the Great Lakes had ever experienced. The ship foundered within seventeen miles of safe haven and went down with all hands to her final resting place at a depth of 530 feet. Canadian folk-singer Gordon Lightfoot first performed his song about the ship in 1976. While the ballad contains many historical inaccuracies, the story and music he created resonated throughout the Great Lakes region and beyond, soon triggering the emotions of an international audience. The ballad quickly hit the top of the pop charts in Canada, the USA, Australia and the UK. The story remains a lasting legacy to both Canada and the USA whose ports the ship regularly visited - and with the seagoing life of the St. Lawrence: "The legend lives on from the Chippewa on down / Of the big lake they call Gitchee Gumee / The lake, it is said, never gives up her dead /When the skies of November turn gloomy."

${ }^{24}$ Eric Atkins, "EU-Canada trade spurs launch of new shipping routes," Globe \& Mail, 21 August 2017, B1. 
In 1941 a delightful childrens' book captured the ebb and flow of life along the great waterways leading to the sea. Holling Clancy Holling's (1900-1973) Paddleto-the-Sea quickly became a classic in its genre. It also captured the dynamic of human interaction along the way. In it a young Indian boy carves a foot-long canoe modelled after his father's big birchbark. The canoe carries a wooden figure and is inscribed with a message to anyone who finds it: "Please put me back in water-I am Paddle-to-the-Sea." Paddle's journey begins on a snow-bank north of the Great Lakes. As the snow melts - and later with the occasional help of people who find him - he embarks on an eventful four-year journey through the Great Lakes and connecting rivers, and down the St. Lawrence River until at last he reaches the Atlantic Ocean. His adventure is a wonderfully engaging introduction to the geography of the great navigable waterways cutting deep into the heart of North America.

Here, where the St. Lawrence meets the ocean washing the shores of Quebec, New Brunswick, Newfoundland, Nova Scotia and Prince Edward Island is the scene of a very rich cultural heritage since the earliest days of Aboriginal life and European settlement. The history is a matter of public record, and is well documented: music, literature, immigration, high-seas commerce, fishing and naval warfare. (I will resist the temptation of highlighting the well-documented Battle of the St. Lawrence, even though German submarines sank Canadian warships, and the ferry SS Caribou where sea meets river in Cabot Strait.) Yet it would be remiss to pass over the scene without some poignant reflection on the nature of war in the great river and gulf.

Narratives about war at sea, it has been argued elsewhere, often indulge in a kind of romanticism untenable on land. ${ }^{25}$ For in land wars, the debris of mortal combat scars the earth. We see it long after the battle is over. Not so at sea where bloody battles between ships on the high seas leaves neither trace of carnage nor sites for national shrines. George Whalley's poem "Battle Pattern" engages the imagination on a number of levels. Although he had written it to mark the sinking of Germany's battleship Bismarck on 27 May 1941, he has infused his poem with his own experience as both wartime officer in the RCNVR and post-war professor of English literature at Queen's University, Kingston. He had served in the waters of St Lawrence and Cabot Strait, and knew the devastation which submarine warfare had wrought "where rivers meet oceans." Thus he could graphically compare and contrast two sets of images: the decaying bodies of war's victims, and the wreckage of ships lying "In the vast silence of the tideless sea-floor / fathoms deep, in the birthless womb of ocean." On the one hand the depths held "the hammered, turned, polished,/ riveted sleekness and sweet beauty of gun;" on the other, the "broken pitiful beauty born of the smooth loins of women."

\footnotetext{
${ }^{25}$ See my Count Not the Dead: the Popular Image of the German Submarine. (Montreal and Kingston: MGill-Queen's University Press, 1995), x.
} 
The seventh, and final canto of his poem picks up the ancient theme of the sea as healer. The theme has fascinated audiences since at least the fifth century BCE when Euripides pronounced in his Iphigenia in Taurus: "The sea washes away the stains and wounds of the world." The notion of the ocean's capacity to cleanse and heal the world of "evil" and "sin" has been picked up and recast throughout history: from Sophocles to the prophet Micah (7:19), to Oscar Wilde and on to our own age of environmentalism. We see, perhaps, only now that Shakespeare had got it right in Macbeth (II, ii). Here Macbeth confesses after the brutal murder he has committed, that human violence is enough to make even the green seas turn blood red. For naval officer and poet George Whalley, however, "Not all laving of all the world's / oceans ... can ever heal the hearts / smashed to fragments of desolated darkness." Indeed, he wrote, "No pity or memory ever ruffled the iron / implacable will of ocean. Yet in its throat / is merciful secrecy, when hope is gone." ${ }^{26}$ That, too, is a living legacy of the broad region where the St. Lawrence meets the sea. Memorials throughout the whole Maritime region bear witness to that legacy.

Another St. Lawrence legacy is the theme of migration and exile. As a young immigration officer in 1960, I myself once "worked" the immigrant ships from Point au Père at Rimouski, up to Quebec City: Greek Lines Arkadia, Home Lines Homeric, CPR vessels Empress of France and Empress of Britain, and the EuropeCanada Line Seven Seas. (Those were the days before air travel was common). Historic sites captured my imagination as I voyaged up-river while stamping passports, and then travelled by train back down to Point au Père in order once more to board the pilot vessel and scramble onto the next inbound immigrant ship.

Grosse Île, in the mouth of the St. Lawrence River, for example, served as a quarantine station for the port of Québec from 1832 to 1937. Its early years witnessed the appalling fate of thousands escaping the Great Irish Famine of 18451849. Weakened by malnutrition, disease, and filthy overcrowded ships, many who survived the nightmare of the transatlantic crossing died of cholera and typhus at Grosse Île. In 1847, at the height of the famine, over 7,500 were buried in the Irish Cemetery there. Over 160 years later, in May 2011, the shores revealed further evidence of death and destruction. As a journalist reported, the "ghosts of history" had emerged from buried bones in the sand, and inspired the modern day descendants of survivors to discover their past. ${ }^{27}$ New stories and national narratives emerged from old lore. Today the Irish Memorial National Historic Site at Grosse Île commemorates the importance of immigration to Canada.

Poet Al Purdy's telling work "Grosse Isle" strikes to the heart of the matter:

\footnotetext{
${ }^{26}$ George Whalley, "Battle Pattern," in The Collected Poems of George Whalley, (Kingston, ON: Quarry Press, 1986), 59-60.

27 Ingrid Peritz, "Bones found on Gaspé coast could be of 1847 shipwreck victims," Globe \& Mail, 19 July 2011, A4.
} 
Look stranger

see your own face reflected in the river

stumble up from the stinking hold

blinded by sunlight and into the leaky dinghy .... .

stumble again and fall when you reach the shore

and bless this poisoned earth

but stranger no longer

for this is home. ${ }^{28}$

Another river with a different history meets the sea in King's County, Nova Scotia: the twenty-four kilometre long Gaspereau that runs into Minas Basin in the Bay of Fundy. It forms part of the UNESCO World Heritage Site of Grand Pré, and is the scene of what Acadians poignantly recall as Le Grand Dérangement-The Great Disruption-The Expulsion of the Acadians in 1755. Longfellow's Evangeline: A Tale of Acadie took up the theme in 1847:

Thus to the Gaspereau's mouth

they hurried; and there on the sea-beach

Piled in confusion

Lay the household goods of the peasants.

Thus to the Gaspereau's mouth moved on that mournful procession. ${ }^{29}$

Over eleven thousand Acadians were sent into exile.

One hundred thirty-two years later - in 1979- Antonine Maillet captured the scene even more dramatically in her novel Pélagie La Charette. The cultural memory of the event was still flourishing. Her novel evokes horrific scenes of burning homes, terror, anguished disbelief, and desperation as families are separated, and children are torn from parents. And in the midst of all the desperate confusion, the hopeless helter-skelter of broken lives, flashes of compassion. Antonine Maillet concludes one such passage with the naked line: "So it is when a people departs into exile." ${ }^{30}$ I myself have stood on that site on the Gaspereau - at dusk - and shall never forget the haunting presence of history made palpable by experience and memory. Maillet's line strikes one as a Zen mantra for human suffering such as we now see every day in the media as refugees seek sanctuary.

\footnotetext{
${ }^{28}$ Al Purdy, Beyond Remembering: The collected poems of Al Purdy (Madeira Park, BC: Harbour Publishing, 2000), 478-80.

${ }^{29}$ Henry W. Longfellow, Evangeline: A Tale of Acadie (1847) (London: Ernst Nister and New York: E.P Dutton, nd.), 70.

${ }^{30}$ Antonine Maillet, Pélagie: The Return to Acadie (French original, 1979; English translation, 1982; Fredericton, NB: Goose Lane Editions, 2004, 13-14.
} 
Literary portraits of Canada's abiding relationship with the sea abound. So, too, do portraits of people. In such art, individual experience and personal transformations become the very stuff of national identity. Poet Charles Bruce (1906 - 1971) understood this when he sketched the portrait of one particular character whose life had been shaped by the sea:

You know his story when you see him climb

The lookout hill. You know that age can be

A hill of looking; and the swaying sea

A lifetime marching with the waves of time.

Listen - the ceaseless cadence, deep and slow.

Tomorrow. Now. And years and years ago. ${ }^{31}$

What is the point of this all-too brief aesthetic and "symbolic" survey of places where rivers meet oceans? Simply put, it supports Jeffrey Hutchings' acknowledgement at the 2016 Symposium of the Royal Society of Canada that the sea is one of the "top keystone narratives of Canadian identity and values." What we are dealing with is not a landscape stretching, as the national motto would have it, "From Sea to Sea." Nor even an external seascape that serves as a highway for geopolitical power projection, or a defensive moat. We have instead an "inscape" in which the surging seas and the pulsing rivers meet - and through its literature, music and culture shape and reshape our national identity. According to this model, historical 'fact' - in the positivist sense of that word - proves to be less vivid and compelling than the complex weave of national narratives which our experiences and cultural memory create.

The reflections I have offered contain nothing but spindrift — wisps of spray streaking across the tops of rolling waves. The lines do nothing more than hint at the wealth of experience and lore - captured in written records and songs, and in the memories of those Canadians who have experienced and imagined the grandeur, wonder and underlying importance of the seas. Beneath these wisps of spray lies a profound dimension of the Canadian relationship to the sea, which awaits exploration. The "wholesome sea" is not merely "at our gates," as these sculptured words proclaim over the entrance to Parliament in Ottawa. The sea is - and has always been - an intrinsic part of our national identity. But to recognize that "fact" we must step outside the principles and methods of our own particular disciplines, and view the contesting perspectives "from the other side of the hill." There is every evidence that Canada is indeed a maritime nation.

\footnotetext{
${ }^{31}$ Charles Bruce, "Eastern Shore," in The Mulgrave Road. (Toronto: Macmillan, 1951). Republished as Andy Wainwright and Lesley Choyce, eds., The Mulgrave Road: Selected Poems of Charles Bruce. (Porters Lake: Pottersfield Press, 1985).
} 